\title{
Early weaning and length of supplementation effects on beef calves
}

\author{
A.J. PORDOMINGO
}

Author is Research Scientist of National Institute of Agricultural Research, INTA Anguil, C.C. 11, Anguil (6326), La Pampa, Argentina.

\begin{abstract}
Early weaning of calves can improve reproduction of beef cows, and would be of no detriment to calf growth if the diet is adequate. Digestible energy intake could be limiting, however, when calves are weaned on forage. Performance of calves weaned at 70 days (early weaning) and 172 days (normally weaning) of age were compared. Calves from 2 locations in Argentina, Anguil, and Chacharramendi, were distributed in 14 groups and half were weaned. Early-weaned calves were pen fed a $50 \%$ concentrate-50\% alfalfa hay diet for 12 days, followed by grazing on alfalfa for 150 days. During the first 90 days on pasture, earlyweaned calves were group supplemented $(1.2 \%$ body weight (BW, DM basis). Calves from Anguil did not differ $(P=0.068)$ in average daily gain (ADG). In contrast, early-weaned calves from Chacharramendi gained faster than normally-weaned calves $(\mathrm{P}<$ 0.01). In a second experiment, 108 calves were classified into 3 age groups on day 0 of trial (AGE1 $=109 \pm 2.2$ days of age, AGE2 $=91 \pm 1.6$ days of age and AGE3 $=75 \pm 3.8$ days of age). Two thirds of the calves were weaned (early-weaned calves) the same day and the remaining third was returned to their dams (normally-weaned calves). Two feeding treatments were imposed on the early-weaned calves: S15 = supplement during the first 15 days on pasture ( $1 \%$ body weight, DM basis), and S45 = supplement during the first $\mathbf{4 5}$ days. Early-weaned calves grazed on an alfalfa pasture for 136 days. Calves from the normally-weaned group remained with their mothers until weaning onto pasture on day 87 of the study. Normally-weaned calves were the heaviest $(P<0.05)$ at the end of trial. Differences in body weight between early weaning ages increased as the supplementation period decreased. Calves that were weaned at 75 days of age and fed supplement for only 15 days had the lowest $(P<0.05)$ overall ADG and final body weight. Overall results suggested that early weaning favors reproduction of thin cows, and early-weaned calves can be placed on good-quality pasture with no detriment of growth if energy supplement is provided.
\end{abstract}

Key Words: Calf growth, calf diet, calf supplementation, beef cattle

This research was funded by National Institute of Agricultural Research. INTA Anguil, La Pampa. Author wishes to thank Carlos Urquiza and his personnel for assistance during field data collection. Appreciation is also extended to Associate Editor Dr. Elaine Grings for her invaluable assistance in reviewing and editing this manuscript.

Manuscript accepted 15 Sept. 01.
Resumen

El destete precoz mejora la eficiencia reproductiva del rodeo y no sería detrimental del crecimiento del ternero si la dieta es adecuada. Sin embargo, cuando los terneros son destetados a forraje, el consumo de energía digestible podría ser limitante del crecimiento. En este estudio se comparó la performance de terneros destetados a los 70 días (destete precoz) o a los 172 días de vida (destete normal). Terneros provenientes de 2 localidades de la provincia de La Pampa en Argentina, Anguil y Chacharramendi, fueron distribuidos en 14 grupos y la mitad se destetaron. Los terneros destetados precozmente fueron alimentados a corral con una dieta $\mathbf{5 0 \%}$ concentrado $\mathbf{- 5 0 \%}$ heno de alfalfa durante 12 días y pasaron luego a pastorear alfalfa por 150 días más. Durante los primeros 90 días sobre la pastura, recibieron un suplemento en grupo $(1,2 \%$ de peso vivo en base seca). Los terneros provenientes de Anguil no difirieron $(P=$ 0.06) en aumento de peso (ADP). En contraste, los terneros provenientes de Chacharramendi destetados precozmente aumentaron a un ritmo mayor $(P<0,01)$ que los destetados normalmente. En un segundo experimento, 108 terneros fueron clasificados en 3 grupos de edad el día 0 del ensayo (EDAD1 = $109 \pm 2,2$ días, EDAD2 $=91 \pm 1,6$ días y EDAD3 $=75 \pm 3.8$ días $)$. Dos tratamientos de suplementación fueron impuestos sobre los terneros destetados precozmente: $\mathbf{S 1 5}=$ suplementación durante 15 días sobre pastura ( $1 \%$ del peso vivo en base seca) y $\mathbf{S 4 5}=$ suplementación durante 45 días. Los terneros de destete precoz pastorearon sobre alfalfa durante 136 días. Los terneros del grupo de destete normal se mantuvieron con sus madres hasta el día 87 del ensayo, momento en el que fueron destetados y trasladados a una pastura de alfalfa (sin suplementación). Los terneros destetados normalmente fueron los más pesados al finalizar el experimento. las diferencias de peso entre edades al momento del destete precoz se incrementaron con el período de suplementación. Los terneros que fueron destetados a los 75 días de vida y suplementados por sólo 15 días tuvieron los menores ( $P$ $<0,05$ ) aumentos de peso y pesos más bajos al finalizar el ensayo. Los resultados de ambas experiencias sugirieron que el destete precoz favorece la reproducción de vacas delgadas y que los terneros destetados precozmente no sufrirían un retraso de su crecimiento si se ofrece un forraje de alta calidad y se provee un suplemento energético.

Early weaning of calves can improve reproduction rates of thin cows (Laster et al. 1973, Lusby and Wetteman 1980, Lusby and Parra 1981, Lusby et al. 1981, 1990, Peterson et al. 1987), and allow for increases in stocking rate (Monje et al. 1978, Hofer et al. 1984, Kugler et al. 1997b). Lusby and Wetteman (1980), and Gill et al. (1993) demonstrated that weaning as early as 55 days 
of age is not detrimental to calf growth. Moreover, early-weaned calves on a highconcentrate diet can gain weight faster than normally weaned calves before weaning (Myers et al. 1999a, 1999b) or even on a finishing program after weaning (Fluharty et al. 2000). Most of this work, however, was done using feedlot diets followed by a feedlot program. Little research has been done with early-weaned calves and high forage diets. The greater the roughage content of the early-weaned calf diet, the lower total energy intake and rate of gain. Hofer et al. (1984) and Monje et al. (1993) showed that early-weaned calves should be placed on good quality pasture and provided supplemental energy if good gains are desired. This research was conducted: a) to evaluate performance of early-weaned calves on pasture with limited amounts of supplementation, and b) to study the interaction between age at weaning and supplementation period on average daily gain of calves. The impact of early weaning on body condition score changes of the dams grazing rangeland at 2 locations was also evaluated.

\section{Materials and Methods}

\section{Experiment 1}

Performance of early-weaned calves weaned at 70 days of age was compared with calves weaned at the normal age of 180 days. Additionally, the impact of early weaning on cow body condition score was evaluated. This trial started on the second week of December and took place during the spring of 1995, and summer and fall of 1996, at INTA (National Institute for Agriculture Research) Anguil Experiment Station. Calves came from of 2 different locations: Anguil, located in the subhumid temperate area of central Argentina (Latitude $36^{\circ} 30^{\prime} \mathrm{S}$ Longitude $63^{\circ} 59^{\prime} \mathrm{W}$, and $165 \mathrm{~m}$ above sea level ; mean annual rainfall $=608 \pm 154 \mathrm{~mm}$, Roberto et al. 1996), and Chacharramendi, located in the semiarid temperate area of the country (Latitude $37^{\circ} 22^{\prime} \mathrm{S}$ Longitude $65^{\circ} 49^{\prime} \mathrm{W}$ and $242 \mathrm{~m}$ above sea level; mean annual rainfall $=465 \pm 143 \mathrm{~mm}$, Roberto et al. 1996).

Medium-frame 5-to-7-year old Angus cows that had calved within a 14-day period, were selected from the herds at Anguil and Chacharramendi. Seventy-two cows were selected at Anguil and 96 cows at Chacharramendi. At both locations, cows grazed on native grassland with no supplemental feed. At about 70 days of age (day
0 of trial: Anguil calves $=70.3 \pm 2.82$, Chacharramendi calves $=70.4 \pm 2.73$ days of age), all calves were weighed and assigned to groups of 12 calves each, with 6 groups in Anguil and 8 groups in Chacharramendi. Groups were made as homogeneous as possible in weight and age of calves within location. Age and body condition of cows were also accounted for in making groups as homogeneous as possible prior to final allocation of calves to treatments. Groups were considered experimental units and were then assigned to either early weaning or normally-weaning treatments at each location.

Body condition of cows was recorded by individual palpation and observation, according to the 9-point body-condition score (BCS) scale: 1 = severely emaciated to $9=$ very obese. At both locations, cows BCS were determined on days $-63,-33,0$, 42,72 , and 102 of the trial at both locations. Day -63 was day 7 of the calving period. At the time about $60 \%$ of the cows had given birth. Cows were exposed to Angus bulls ( 3 and 4 bulls for Anguil and Chacharramendi, respectively) during an 84-day period beginning on day 3 of the trial. Cows were pregnancy checked by rectal palpation 75 days after the end of breeding.

To evaluate diet quality at the 2 locations, fecal samples were collected from 20 cows at random from each herd at the same time of body condition scoring from October to March. Immediately after collection, samples were dried at $60^{\circ} \mathrm{C}$ for 48 hours and ground in a Wiley mill to pass a 1-mm screen. Similar aliquots in weight from each fecal sample were taken and composited into a pooled sample for each location and sampling time. Micro-histological analysis was performed on the pooled sample to determine botanical composition and relative proportions of main species and species classes. Samples

Table 1. Composition of feed and forages provided to early-weaned calves.

Experiment 1

\begin{tabular}{lccccc}
\hline \hline & $\mathrm{CP}^{1}$ & NDF & ADF & ME & Available forage \\
\hline Concentrate feed $^{2}$ & $(\%)$ & $(\%)$ & $(\%)$ & $\left(\mathrm{Mcal} \mathrm{kg} \mathrm{DM}^{-1}\right)$ & $\left(\mathrm{kg} \mathrm{DM} \mathrm{ha}^{-1}\right)$ \\
Alfalfa hay $_{\text {Mixed supplement }}{ }^{3}$ & 18.2 & 15.0 & 8.0 & 2.97 & \\
$\quad$ Alfalfa pasture & 17.5 & 50.3 & 40.3 & 2.08 & \\
December 1995 & 18.0 & 19.2 & 10.3 & 2.92 & \\
January 1996 & 17.8 & 47.8 & 38.2 & & \\
February 1996 & 15.1 & 55.1 & 43.2 & 1.99 & 2850 \\
\hline
\end{tabular}

${ }^{1} \mathrm{CP}=$ crude protein $($ Kjeldhal $\mathrm{N} * 6.25), \mathrm{NDF}=$ Neutral detergent fiber, $\mathrm{ADF}=$ Acid detergent fiber, $\mathrm{ME}=$ Metabolizable energy (NRC 1996). All nutrients are expressed on DM basis.

${ }^{2}$ Commercial feed based on: oat grain, sorghum grain, corn, sunflower meal and soybean meal, mineral salt, Ca and $\mathrm{P}$ organic sources, and a vitamin- micro mineral premix.

${ }^{3}$ Mixed feed composition: $40 \%$ oats, $40 \%$ corn, $18 \%$ soybean meal, $1 \%$ vitamin-mineral premix. 
weaned calves were placed in their corresponding alfalfa pasture until the end of trial (day 162).

Early-weaned calves were supplemented daily during the first 90 days on pasture. Supplement was offered at $1.2 \%$ of average body weight on DM basis within group. Supplement quantity was adjusted every 15 days based on actual BW or calculated BW assuming an ADG of $500 \mathrm{~g}$. For the first 10 days on pasture, the supplement was the same as that fed in drylot. Afterwards, a concentrate mixture based on oat grain, corn and soybean meal was fed (Table 1). The supplement was offered once daily at 1100 hours. A mixture of $50 \%$ salt and $50 \%$ bone meal was present in feeders at all times.

Calves on the normally-weaning treatment were weaned on day 102 of trial (172 \pm 2.73 days of age), which also coincided with the last day of supplementation of early-weaned calves. Normally weaned calves were placed on pasture in assigned paddocks, which had been grazed by nonexperimental steers to remove accumulated mature forage and promote growth of high-quality forage, similar to forage being grazed by early-weaned calves. Groups grazed simultaneously for an additional 60-day period.

All calves were weighed at the beginning of the experiment and on days 42,72 , 102,132 , and 162 of trial, equivalent to days $30,60,90,120$, and 150 on pasture for early-weaned calves. First body weight measurements were taken 5 hours after weaning, but all other BW were recorded after a 17-hour fast without access to feed and water.

Beginning on day 10 of the study, forage DM availability of alfalfa was determined every 30 days. Five $1-\mathrm{m}^{2}$ quadrants per paddock were hand-clipped to a $5-\mathrm{cm}$ height and weighed to determine yield. One sub-sample was taken to determine DM (AOAC 1990), while another was reserved for chemical analysis. Samples of feed offered in pens during the 12-day pen feeding period was taken every 4 days and samples of the supplement offered on pasture were taken every 15 days. These samples were oven dried at $60^{\circ} \mathrm{C}$ to determine DM content and kept for later chemical analysis. Forage samples from each paddock were composited within sampling period. Composites were analyzed for $\mathrm{CP}$ (AOAC 1990), neutral detergent fiber (NDF) (Robertson and Van Soest 1981), and acid detergent fiber (ADF) (Goering and Van Soest 1970) and in vitro DM digestibility (IVDMD) (Tilley and Terry 1963). Metabolizable energy (ME) was calculated from IVDMD estimates (NRC 1996)

\section{Experiment 2}

This trial took place at INTA Anguil Experiment Station. The objective of the study was to determine the effects of age at early weaning and length of supplementation period on calf performance. One hundred and eight medium-frame Angus calves (70 to 105 days of age) were classified into 3 age groups on day 0 of trial. Age groups were defined as: AGE1 $=111$ \pm 2.2 days of age (oldest), AGE2 $=91 \pm$ 1.6 days of age (intermediate), and AGE3 $=75 \pm 3.8$ days of age (youngest). Two thirds of the calves from each age group were weaned(early-weaned calves) the same day and the remaining third was returned to the dams for later weaning (normally-weaned calves). After a penfeeding period of 12 days, early-weaned calves grazed on an alfalfa pasture for 136 days. Two supplementation periods were imposed on the early-weaned calves: S15 $=$ supplement during the first 15 days on pasture (1\% of body weight, DM basis), and $\mathrm{S} 45=$ supplement during the first 45 days on pasture. Supplementation of S15 and S45 calves were concluded on day 27 and 57 , respectively.

Calves from the normally-weaned group, remained with their mothers on native rangeland until weaning onto pasture on day 87 of the study. At that time, age groups averaged 196, 178, and 162 days of age for age groups, AGE1, AGE2 and AGE3, respectively. Comparisons of performance of calves weaned at less than 100 days of age with calves weaned at ages ranging from 5 to 7 months were of interest for inferences to an ample array of cow-calf programs common in our region.

The design assumed supplementation periods (S15 and S45) and nursing as 3 feeding alternatives crossed by 3 age groups. The combination of 3 age groups x 3 feeding alternatives resulted in 9 treatments with 12 calves each. Calves within each treatment were blocked by weight at

Table 2. Composition of feed and forages provided to early-weaned calves.

Experiment 2

\begin{tabular}{lcccc}
\hline \hline & $\mathrm{CP}^{1}$ & NDF & ADF & ME \\
\hline & $(\%)$ & $(\%)$ & $(\%)$ & (Mcal kg DM $^{-1}$ ) \\
Concentrate feed $^{2}$ & 18.2 & 15.0 & 8.0 & 2.97 \\
Alfalfa hay & 17.2 & 48.2 & 39.1 & 2.11 \\
Alfalfa pasture & & & & 2.18 \\
December 1996 & 18.2 & 45.1 & 36.6 & 2.06 \\
January 1997 & 16.1 & 55.0 & 42.4 & 2.14 \\
February 1997 & 16.3 & 47.3 & 37.8 & 2.24 \\
March 1997 & 17.8 & 43.1 & 34.3 & \\
\hline
\end{tabular}

${ }^{\mathrm{CP}}=$ crude protein, $\mathrm{NDF}=$ Neutral detergent fiber, $\mathrm{ADF}=$ Acid detergent fiber, $\mathrm{ME}=$ calculated metabolizable energy (NRC 1996). All nutrients are expressed on DM basis.

Commercial feed based on: oat grain, sorghum grain, corn, sunflower meal and soybean meal. Included also: mineral salt, $\mathrm{Ca}$ and $\mathrm{P}$ organic sources, and a vitamin- micro mineral premix. initiation of the experiment in 3 weight groups, with 4 calves each. These groups were defined as experimental units.

Early-weaned calves were fed a diet of $50 \%$ chopped alfalfa hay and $50 \%$ concentrate for 12 days (Table 2), followed by grazing of alfalfa pasture for 136 days with supplementation according to treatments. A 40-ha pasture was divided in 27 paddocks (1.45 ha each). Paddocks were assigned randomly to each experimental unit. Supplemental feed (Table 2) was the same concentrate as in pens, offered at $1 \%$ of BW (on DM basis) daily at 1100 hours, calculated on the group BW average.

Immediately after weaning, normallyweaned calves were distributed in the previously assigned weight block within age group and moved to the corresponding alfalfa paddock. Paddocks had been grazed by non-experimental steers before arrival of calves to remove accumulated mature forage, encourage regrowth and maintain forage quality. Calves from normally-weaned group remained on pasture for 49 days (day 148 of trial - end of the study), and received no supplemental feed at any time.

All calves were weighed and weights recorded on days $0,27,57,87,117$, and 148 of trial, comprising 5 periods. Procedures for animal weighing, and alfalfa pasture and feed sampling were the same as described in Experiment 1.

\section{Statistical Analysis}

Data of each experiment were statistically analyzed using GLM procedures of SAS (1991) for repeated measures ANOVA. Calf group served as experimental units in each trial. Factor means were separated using LSD (predicted difference method, SAS 1991) when significant $(\mathrm{P}<$ $0.05) \mathrm{F}$ tests were observed. Body weight and ADG of Experiment 1 were analyzed under a randomized complete block design, with weaning treatment as main 
effect, location, and period in the sub-plot (repeated measures factor). Treatment effect, treatment $x$ location, calf group(treatment), period, treatment $\mathrm{x}$ period and the 3-way interaction (treatment $\mathrm{x}$ location $\mathrm{x}$ period) were included in the model. One-way ANOVA was performed by location and period if an interaction weaning treatment $\mathrm{x}$ location $\mathrm{x}$ period was noted $(\mathrm{P}<0.05)$. Effects of diet shifts were also assessed by ANOVA of period effect using GLM procedure of SAS (1991). The model included period, calf group(period), location and period x location. If an interaction of period by location was detected $(\mathrm{P}<0.05)$, interaction means were reported.

Experiment 2 was designed as a completely randomized design with a $3 \times 3$ factorial arrangement of treatments (AGE $x$ FA) in the main plot and period in the sub-plot (repeated measures). Factors AGE, FA and the AGE x FA interaction, period, and the 3-way interaction (FA $x$ AGE $x$ Period) were included in the model. Period effects were analyzed within FA by ANOVA with GLM of SAS with a completely randomized design. Interaction means were reported if a meaningful interaction was detected $(\mathrm{P}<$ $0.05)$.

\section{Results and Discussion}

\section{Experiment 1}

At initiation of the experiment, age of cows was very similar between treatments within location (Anguil $=5.96 \pm 0.745$ years, $(\mathrm{P}=0.875)$; Chacharramendi $=6.01$ \pm 0.736 years; $P=0.890)$. Body condition of cows was also similar (Anguil $=5.42 \pm$ $0.576, \mathrm{P}=0.710$; Chacharramendi $=3.85$ $\pm 0.405, \mathrm{P}=0.6154)$. Calf body weight did not differ either (Anguil $=77.1 \pm 0.11$ $\mathrm{kg}, \quad \mathrm{P}=0.492$; Chacharramendi $=77.6 \pm$ $0.12 \mathrm{~kg}, \mathrm{P}=0.766$ ) among weaning treatments within location at day 0 .

Supply of alfalfa forage was adequate to ensure that both forage quality and quantity did not restrict calf growth (Table 1). A significant interaction $(\mathrm{P}<0.01)$ was detected between location and weaning treatment for calf performance, therefore, weaning effects are reported by location (Tables 3 and 4). Performance of earlyweaned calves from Anguil and Chacharramendi herd was similar $(\mathrm{P}=$ 0.89 ) from day 10 to day 102 of trial when the supplementation was being fed on pasture (Table 3).
Table 3. Average daily gain $\left(\mathrm{g} \mathrm{animal}^{-1}\right)$ of Angus calves weaned at $70(\mathrm{EW})$ or $172(\mathrm{NW})$ days of age from 2 locations 1 .

\begin{tabular}{|c|c|c|c|}
\hline Day of trial & EW calves ${ }^{1}$ & NW & $\mathrm{SE}^{2}$ \\
\hline $\begin{array}{l}0 \text { to } 42 \\
42 \text { to } 72 \\
72 \text { to } 102 \\
102 \text { to } 132 \\
132 \text { to } 162 \\
\mathrm{SE}^{3} \\
0 \text { to } 102 \\
102 \text { to } 162 \\
0 \text { to } 162\end{array}$ & $\begin{array}{l}598^{\mathrm{bA}} \\
592^{\mathrm{bA}} \\
632^{\mathrm{cA}} \\
528^{\mathrm{aA}} \\
527^{\mathrm{aA}} \\
7.9 \\
607^{\mathrm{A}} \\
527^{\mathrm{A}} \\
577^{\mathrm{A}}\end{array}$ & 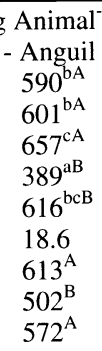 & $\begin{array}{c}10.8 \\
6.6 \\
10.9 \\
16.7 \\
8.0 \\
\\
4.5 \\
5.3 \\
4.8\end{array}$ \\
\hline $\begin{array}{l}0 \text { to } 42 \\
42 \text { to } 72 \\
72 \text { to } 102 \\
102 \text { to } 132 \\
132 \text { to } 162 \\
\text { SE } \\
0 \text { to } 102 \\
102 \text { to } 162 \\
0 \text { to } 162\end{array}$ & $\begin{array}{l}592^{\mathrm{bA}} \\
602^{\mathrm{bA}} \\
632^{\mathrm{cA}} \\
54^{\mathrm{aA}} \\
540^{\mathrm{aA}} \\
7.6 \\
607^{\mathrm{A}} \\
540^{\mathrm{A}} \\
582^{\mathrm{A}}\end{array}$ & $\begin{array}{c}\text { hacharran } \\
371^{\mathrm{bB}} \\
364^{\mathrm{bB}} \\
337^{\mathrm{aB}} \\
336^{\mathrm{aB}} \\
477^{\mathrm{cB}} \\
7.1 \\
359^{\mathrm{B}} \\
407^{\mathrm{B}} \\
377^{\mathrm{B}}\end{array}$ & $\begin{array}{r}9.4 \\
5.7 \\
9.4 \\
14.4 \\
7.0\end{array}$ \\
\hline
\end{tabular}

${ }^{\mathrm{A}}$ treatment $\mathrm{x}$ location $\mathrm{x}$ period interaction was detected $(\mathrm{P}<0.001)$; therefore treatment means are reported by location and period.

${ }^{2} \mathrm{SE}=$ Standard error for weaning effect within period and location

${ }^{3} \mathrm{SE}=$ Standard error for period effect within weaning treatment and location.

${ }^{a b c}$ Means in columns within weaning treatment and location with different lowercase superscripts differ $(\mathrm{P}<0.05)$.

${ }^{\mathrm{AB}}$ Means in rows with different uppercase superscript differ $(\mathrm{P}<0.05)$.

\section{Anguil}

Cows from Anguil were in good body condition at early weaning time and remained in good condition until all calves were weaned (Table 5). However, differences in BCS in favor of cows from the early weaning treatment were noted $(\mathrm{P}<$ $0.05)$ as time progressed. Pregnancy rate was $97 \%$ and $92 \%$ for cows from early weaning and normal weaning treatments, respectively. Table 6 shows composition and quality of the plant classes that com- prised the diet of Anguil cows during spring and summer. Most of the native forage available was perennial grasses. Crude protein and IVDMD data indicated that quality would have not been a limiting factor for milk production and body condition retention on the cows, and it did not imposed major restrictions to the calves' forage intake.

No differences between treatments were detected $(\mathrm{P}=0.33)$ in ADG of calves for the first 102 days of trial (Table 3 ).
Table 4. Live weight $(\mathrm{kg})$ of calves weaned at $70(\mathrm{EW})$ or $172(\mathrm{NW})$ days of age from 2 locations ${ }^{1}$.

\begin{tabular}{|c|c|c|c|}
\hline Day of trial & EW & NW & $\mathrm{SE}^{2}$ \\
\hline & \multicolumn{3}{|c|}{ 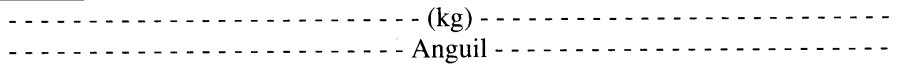 } \\
\hline 0 & 77.1 & 77.2 & 0.06 \\
\hline 42 & 102.2 & 101.9 & 0.46 \\
\hline 72 & 120.2 & 120.4 & 0.47 \\
\hline 102 & 139.0 & 139.7 & 0.44 \\
\hline 132 & 154.8 & $151.4 * *$ & 0.26 \\
\hline \multirow[t]{2}{*}{162} & 170.6 & 169.8 & 0.28 \\
\hline & \multicolumn{3}{|c|}{$\ldots$} \\
\hline 0 & 77.6 & 77.7 & 0.05 \\
\hline 42 & 102.5 & $93.2 * *$ & 0.40 \\
\hline 72 & 120.6 & $104.2^{* *}$ & 0.41 \\
\hline 102 & 139.5 & $114.3 * *$ & 3.38 \\
\hline 132 & 155.7 & $124.4 * *$ & 0.22 \\
\hline 162 & 171.9 & $138.7 * *$ & 0.24 \\
\hline
\end{tabular}

${ }^{A}$ treatment $x$ location $x$ period interaction was detected $(\mathrm{P}<0.001)$; therefore treatment means are reported by location and period

${ }^{2} \mathrm{SE}=$ Standard error

** Means in rows differ $(\mathrm{P}<0.01)$ 
Table 5. Body condition scores (BCS) ${ }^{1}$ of cows with calves weaned at 70 (EW) or 172 (NW) days of age at 2 locations, Anguil and Chacharramendi.

\begin{tabular}{|c|c|c|c|c|}
\hline $\begin{array}{l}\text { Day after } \\
\text { calving }\end{array}$ & $\begin{array}{c}\text { Day of } \\
\text { trial }^{3}\end{array}$ & EW & NW & $\mathrm{SE}^{2}$ \\
\hline 1 & -63 & 5.67 & 5.64 & 0.12 \\
\hline 30 & -33 & 5.53 & 5.50 & 0.11 \\
\hline 63 & 0 & 5.42 & 5.47 & 0.10 \\
\hline 105 & 42 & 5.47 & 5.36 & 0.10 \\
\hline 135 & 72 & $5.58 \mathrm{a}$ & $5.19 b$ & 0.10 \\
\hline \multirow[t]{2}{*}{165} & 102 & $5.61 \mathrm{a}$ & $5.03 \mathrm{~b}$ & 0.10 \\
\hline & - . - . & $\ldots$ & 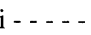 & $\ldots$ \\
\hline 1 & -63 & 5.07 & 5.17 & 0.08 \\
\hline 30 & -33 & 4.89 & 4.94 & 0.09 \\
\hline 63 & 0 & 4.40 & 4.44 & 0.09 \\
\hline 105 & 42 & 3.83 & 3.88 & 0.06 \\
\hline 135 & 72 & $4.52 \mathrm{a}$ & $3.80 \mathrm{~b}$ & 0.06 \\
\hline 165 & 102 & $5.05 \mathrm{a}$ & $3.72 \mathrm{~b}$ & 0.07 \\
\hline
\end{tabular}

Body condition score: $1=$ severely emaciated, $2=$ emaciated, $3=$ very thin, $4=$ thin, $5=$ moderate, $6=$ good, $7=$ very good, $8=$ obese, 9 = very obese

${ }^{2} \mathrm{SE}=$ Standard error

${ }^{3}$ Day 0 of trial were dates December 4th and 5th for locations Anguil and Chacharramendi, respectively.

${ }^{\mathrm{a}, \mathrm{b}}$ Means in rows with different superscript differ $(\mathrm{P}<0.05)$

Likewise, calf treatment groups from Anguil did not differ $(\mathrm{P}=0.48)$ in $\mathrm{BW}$ at day 0 or days 42,72 , and 102 (Table 4 ).

On day 102, supplemental feeding of early-weaned calves was concluded and normally-weaned calves were weaned. Comparisons across periods within weaning treatment indicated that diet switch resulted in reduction $(\mathrm{P}<0.01)$ of gain for the following 30 -day period in both groups (Table 3). Feeding normally-weaned calves after weaning on alfalfa forage without supplemental feed, had a greater depressive effect $(\mathrm{P}=0.016)$ on $\mathrm{ADG}$ than supplement elimination for early-weaned calves grazed on the same forage. Normally-weaned calves appeared to express compensatory growth the following 30 days, showing greater $(P=0.015)$ ADG than early-weaned calves. Overall, performance of early-weaned and normally-weaned calves was similar $(\mathrm{P}=0.168)$.

\section{Chacharramendi}

Weaning treatment groups from Chacharramendi were similar $(P=0.77)$ in average body weight of calves at early weaning time (Table 4). Early-weaned calves, however, gained more $(\mathrm{P}<0.01)$ than normally-weaned calves over the study (Table 3 ). At normal weaning time (day 102 of trial; 172 days of age), earlyweaned calves averaged $25 \mathrm{~kg}$ heavier than normally-weaned calves (Table 4). The ADG of early-weaned calves was almost twice $(\mathrm{P}<0.01)$ that of normally-weaned calves during this period (Table 3 ).

The area suffered a 5-month drought during spring and summer. Although spring is statistically the rainy season $(54 \%$ of the annual rainfall) (Roberto et al. 1996), Spring 1995 was unusually dry. The accumulated rainfall at the ranch for Spring 1995 and Summer 1996 was 58\% $(202 \mathrm{~mm})$ of the 80 -year average $(345 \mathrm{~mm}$; Roberto et al. 1996). The Chacharramendi cow herd lost 0.7 units of body condition (from $5.1 \pm 0.2$ to $4.4 \pm 0.56$ ) from calving to day 0 of trial (Table 5). Early weaning allowed the cows to recuperate body condition during summer. Cows that remained with their calves continued to lose condition up to weaning (day 165 after calving). Pregnancy results reflected the body condition differences $(91 \%$ and $44 \%$ for cows on early weaning and normal weaning treatments, respectively.)

Although not measured directly, a reduced forage availability and quality would have restricted milk production and calf's feed intake, which would have been detrimental for calf growth. Microhistology on fecal samples from parturition to the normal weaning time pointed out an increased presence of shrubs in the diet during the late spring and summer months (Table 6), which could indicate a sizable reduction of grass availability. Although shrubs provided a greater proportion of crude protein than perennial grasses, lignin content also increased and digestibility decreased. Compared with the diet of the herd at Anguil, the cow herd at Chacharramendi had a lower quality forage available from calving and throughout the study.

Normally-weaned calves from Chacharramendi suffered a diet adjustment effect as did normally-weaned calves from Anguil during the 30-day period after weaning. Gains of early-weaned calves did not improve in this period compared with the previous one (Table 3 ). This group expressed some compensatory growth in the last 30-day period of the study, but not as great as in Anguil. This increase did not compensate for the reduced rate of growth that took place up to weaning. Over the study, ADG of earlyweaned calves was $54 \%$ greater than gain of normally-weaned calves (Table 3). At the end of trial, early-weaned calves were $33.2 \mathrm{~kg}$ heavier $(\mathrm{P}<0.01)$ than normallyweaned ones (Table 4 ).

Results from our study would indicate that early-weaned calves grazing good quality pastures and supplemented for a 90-day period would grow at a rate similar to normally-weaned calves if cows can maintain good body condition through lactation. Moreover, ADG of early-weaned calves could be superior to ADG of normally-weaned calves if cows were under nutritional stress. Fernández and Zuccari (1996), in a similar environment and weaning program, reported no differences in weight gain of Angus calves weaned from first calf heifers at 60 days of age and supplemented on pasture during 60 days, compared with calves weaned at 6 months of age. Daily gains reported were $679 \mathrm{~g}_{\text {animal }}{ }^{-1}$ for early-weaned vs $670 \mathrm{~g}$ animal $^{-1}$ for normally-weaned calves. In a similar study, Fernández et al. (1997) reported ADG of 646 and $644 \mathrm{~g} \mathrm{animal}^{-1}$ for early-weaned and normally-weaned calves.

In Oklahoma, Lusby and Wettemann (1980) reported similar rates of growth up to 7 months of age for normally-weaned calves and calves weaned at $56 \mathrm{~kg}$ body weight (6 to 8 weeks of age). Drylot-fed early-weaned calves gained weight at a rate of $667 \mathrm{~g} \mathrm{day}^{-1}$.

In a more restrictive environment than ours (Province of Río Negro, Argentina) and a similar feeding program, Kugler et al. (1997a) reported greater ADG for 69day old early-weaned calves compared with normally-weaned calves (745 vs 580 $\mathrm{g}$ animal $\left.{ }^{-1}\right)$. After weaning, the earlyweaned calf group was supplemented during 60 days on pasture. In contrast, Sciotti et al. (1996) reported lower ADG for early-weaned calves supplemented for 30 days on pasture compared with normallyweaned calves ( 578 vs $635 \mathrm{~g}^{\text {animal }}{ }^{-1}$ ). Working in a more humid area of Argentina, Hidalgo et al. (1996) reported better performance of normally-weaned calves than early-weaned calves (900 vs $493 \mathrm{~g} \mathrm{day}^{-1}$ ). 
Table 6 . Botanical composition1, and quality of forage classes and estimated diet of beef cows at 2 locations.

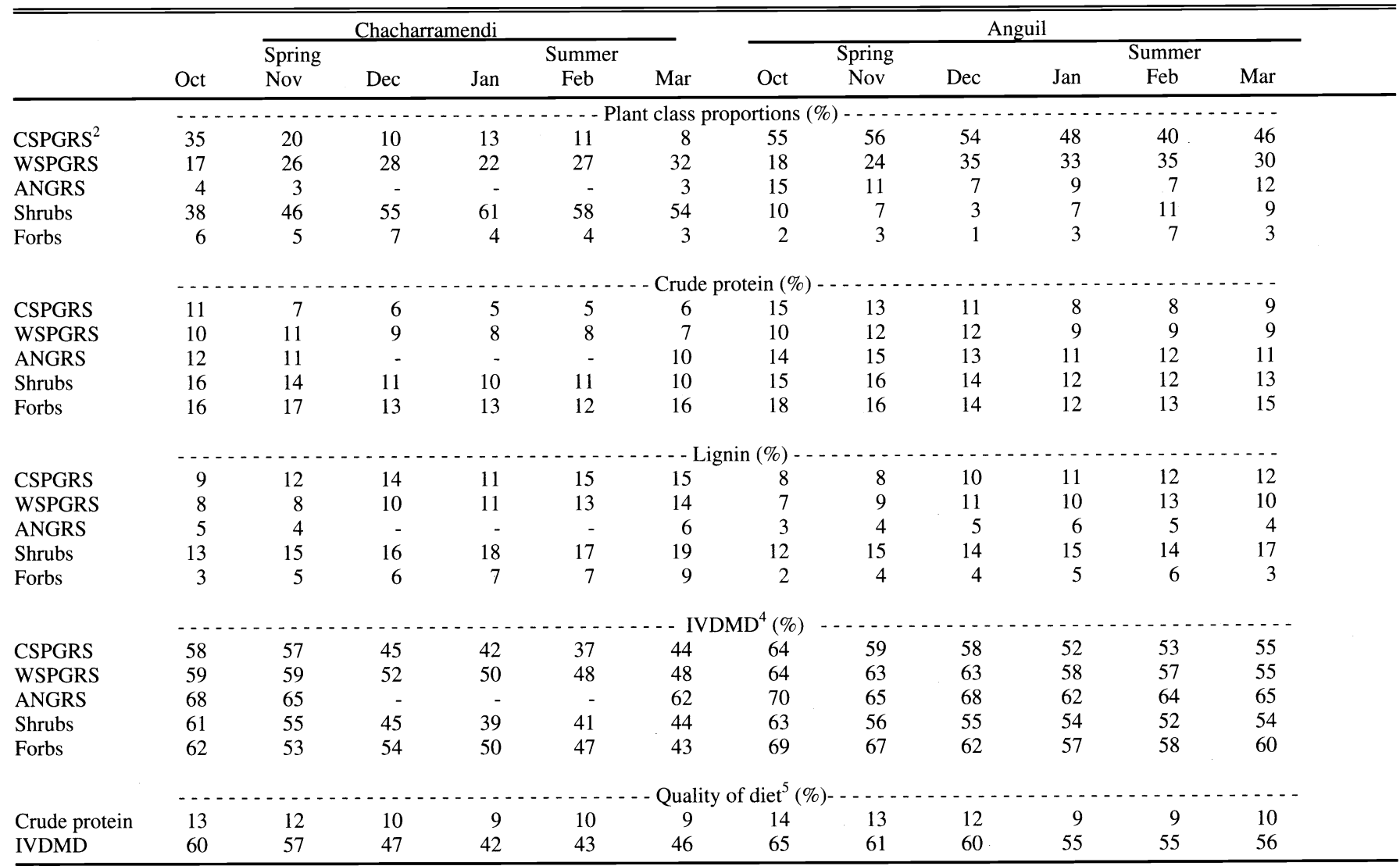

Estimated by microhistology of fecal samples

${ }^{2}$ CSPGRS = Cool-season perennial grasses; WSPGRS = Warm-season perennial grasses; ANGRS = Annual grasses

${ }_{4}^{3}$ Kjeldahl N x 6.25

${ }^{4}$ In vitro dry matter digestibility

${ }^{5}$ Calculated from class proportion and quality data

\section{Experiment 2}

Available biomass in alfalfa pastures was greater than $2200 \mathrm{~kg} \mathrm{DM} \mathrm{ha}{ }^{-1}$ throughout the 148-day study period and calf intake should not have been restricted. Table 2 shows nutrient composition of feeds and forage used in the study. The normally-weaned calves were heaviest $(P$ $<0.01$ ) at the end of trial, compared with early-weaned ones, within age groups (Table 7), and differences increased as age at weaning decreased. Calves from the normal weaning treatment were 15 and 13 $\mathrm{kg}$ heavier in the oldest group (AGE1), 18 and $15 \mathrm{~kg}$ in the intermediate (AGE2), and 31 and $23 \mathrm{~kg}$ in the youngest (AGE3), compared with the 15-day supplemented and 45-day supplemented early-weaned calves, respectively. Within the normal weaning treatment, a decrease in ADG with decreasing age was detected $(\mathrm{P}<$ 0.05 ) in period 1 (Table 8). Gains, however, did not differ $(P>0.28)$ between age groups in periods 2 and 3 . Despite the cited initial effect, ADG of all age groups of normally-weaned calves did not differ
$(\mathrm{P}>0.43)$ over the pre-weaning period (accumulated periods 1, 2, and 3).

Before normal weaning time, ADG was usually greater $(P<0.01)$ in normallyweaned calves compared to early-weaned calves, within each period and age group (Table 8). Differences became larger as days progressed and early-weaned calves were deprived of supplemental feed (periods 1, 2, and 3). During the 30-day period after weaning (period 4), normally-weaned calves showed lower $(\mathrm{P}<0.01)$ ADG, compared with the previous period. In this period, the youngest group of normallyweaned calves had lower $(\mathrm{P}<0.05)$ ADG than the oldest and the intermediate age group, possibly showing a detrimental effect of weaning 162-day old calves onto a $100 \%$ pasture diet. Average daily gain of normally-weaned calves within age group in period 4 did not differ $(P>0.28)$ from gain of 15-day supplemented and 45-day supplemented early-weaned calves.

Thirty days later (period 5), normallyweaned calves showed increased $(\mathrm{P}<$ 0.05) ADG compared with earlier periods.
Moreover, the youngest group had greater $(\mathrm{P}<0.05)$ ADG, compared with the other 2 , and the greatest ADG of the study, likely expressing compensatory growth. Likewise, ADG of these calves was greater $(\mathrm{P}<0.01)$ than ADG of earlyweaned calves within all age groups in this period. Over the study, no differences $(\mathrm{P}=$ 0.58 ) in ADG were detected between age groups for normally-weaned calves.

Age at early weaning date (day 0 of trial) correlated highly with body weight ( $\mathrm{r}$ $=0.97$ ). The youngest calves were 16 days younger and $15 \mathrm{~kg}$ lighter than those in the intermediate group. In turn, the intermediate group was 18 days younger and $20 \mathrm{~kg}$ lighter than the oldest. Body weight differences among age groups noted at early weaning time remained significant $(\mathrm{P}<$ 0.05 ) for each sampling period and across the study. Within the supplementation treatments of early-weaned calves, the heaviest calves at early weaning time were also the heaviest at the end of trial $(\mathrm{P}<$ $0.05)$. The shortest supplementation period magnified ADG differences due to age. 
Table 7. Weight of Angus calves early weaned (EW) at 3 different ages and supplemented on pasture for 15 (S15) or 45 (S45) days, compared with weight of calves of corresponding ages at early weaning time and normally weaned $(\mathrm{NW})^{1,2}$.

\begin{tabular}{|c|c|c|c|c|c|}
\hline \multirow{2}{*}{$\begin{array}{l}\text { Age at } \\
\text { early weaning }\end{array}$} & \multirow{2}{*}{$\begin{array}{c}\text { Days of } \\
\text { trial }\end{array}$} & \multicolumn{2}{|c|}{ EW calves } & \multicolumn{2}{|c|}{ NW calves } \\
\hline & & $\overline{\mathrm{S} 15}$ & S45 & & $\mathrm{SE}^{4}$ \\
\hline & & $\cdots A$ & ion of th & ys) - - & $\cdots$ \\
\hline AGE1 & 0 & 108 & 110 & 110 & 2.4 \\
\hline AGE2 & 0 & 92 & 91 & 91 & 1.0 \\
\hline AGE3 & 0 & 78 & 73 & 75 & 3.1 \\
\hline $\mathrm{SE}^{5}$ & & 1.8 & 3.1 & 1.9 & \\
\hline & & $\cdots$ & Neight* & & -- \\
\hline AGE1 & 0 & 115 & 114 & 114 & 2.0 \\
\hline AGE2 & 0 & 94 & 94 & 94 & 1.7 \\
\hline AGE3 & 0 & 79 & 80 & 79 & 1.4 \\
\hline SE & & 1.8 & 2.0 & 1.3 & \\
\hline AGE1 & 27 & 132 & 131 & 132 & 2.2 \\
\hline AGE2 & 27 & 110 & 110 & 111 & 1.7 \\
\hline AGE3 & 27 & 94 & 95 & 96 & 1.5 \\
\hline SE & & 1.8 & 2.2 & 1.3 & \\
\hline AGE1 & 57 & $147^{\mathrm{a}}$ & $150^{\mathrm{ab}}$ & $152^{\mathrm{b}}$ & 2.3 \\
\hline AGE2 & 57 & $123^{\mathrm{a}}$ & $128^{\mathrm{b}}$ & $131^{\mathrm{b}}$ & 1.7 \\
\hline AGE3 & 57 & $104^{\mathrm{a}}$ & $112^{\mathrm{b}}$ & $117^{\mathrm{c}}$ & 1.5 \\
\hline SE & & 1.8 & 2.3 & 1.2 & \\
\hline AGE1 & 87 & $162^{\mathrm{a}}$ & $164 a$ & $172^{\mathrm{b}}$ & 2.4 \\
\hline AGE2 & 87 & $137^{\mathrm{a}}$ & $141 \mathrm{a}$ & $151^{\mathrm{b}}$ & 1.8 \\
\hline AGE3 & 87 & $116^{\mathrm{a}}$ & $124 b$ & $136^{\mathrm{c}}$ & 1.7 \\
\hline SE & & 1.8 & 2.4 & 1.3 & \\
\hline AGE1 & 117 & $178^{\mathrm{a}}$ & $180^{\mathrm{a}}$ & $187^{\mathrm{b}}$ & 2.5 \\
\hline AGE2 & 117 & $153^{\mathrm{a}}$ & $157^{\mathrm{a}}$ & $167^{\mathrm{b}}$ & 1.9 \\
\hline AGE3 & 117 & $129^{\mathrm{a}}$ & $137^{\mathrm{b}}$ & $150 \mathrm{c}$ & 2.6 \\
\hline SE & & 2.0 & 2.6 & 1.6 & \\
\hline AGE1 & 148 & $194^{\mathrm{a}}$ & $196^{\mathrm{a}}$ & $209^{\mathrm{b}}$ & 2.6 \\
\hline AGE2 & 148 & $170^{\mathrm{a}}$ & $173^{\mathrm{a}}$ & $188^{\mathrm{b}}$ & 1.8 \\
\hline AGE3 & 148 & $143^{\mathrm{a}}$ & $151^{\mathrm{b}}$ & $174^{\mathrm{c}}$ & 2.6 \\
\hline $\mathrm{SE}$ & & 2.2 & 2.8 & 1.8 & \\
\hline
\end{tabular}

Calves of the NW treatment were kept with the dams until day 87 of trial; NW calves reached the ages 196, 178, and 162 days, for AGE1, AGE2 and AGE3, respectively.

${ }^{2} \mathrm{~A}$ weaning treatment $\mathrm{x}$ age group $\mathrm{x}$ period interaction was detected $(\mathrm{P}<0.001)$; therefore, interaction means are reported.

${ }^{3}$ Age groups at early weaning date: AGE1 $=111 \pm 2.2$ days of age; AGE2 $=91 \pm 1.6$ days of age, and AGE3 $=75 \pm 3.8$ days of age.

${ }^{4} \mathrm{SE}=$ Standard error for diet effect.

${ }^{5} \mathrm{SE}=$ Standard error for age group effect.

*Weight differences between age groups within period and diet treatment are all significant $(\mathrm{P}<0.05)$

${ }^{a b c}$ Means in rows with different superscripts differ $(\mathrm{P}<0.05)$.

Feeding supplement for only 15 days detrimentally affected the youngest group at early weaning. After 148 days, the 15day and 45-day supplemented calves from the oldest early-weaned group (AGE1) were 23 and $24 \mathrm{~kg}$ heavier $(\mathrm{P}<0.05)$ than calves from corresponding groups of the intermediate age at early weaning (AGE2). No supplementation effect was detected $(\mathrm{P}>0.34)$ within these 2 age groups. Differences, however, between the oldest (AGE1) and youngest (AGE3) calves were greater $(\mathrm{P}<0.05)$ in the 15 day than in the 45-day supplementation treatment (52 and $45 \mathrm{~kg}$, respectively).

Body weight and ADG did not differ ( $P$ $>0.26$ ) between supplementation treatments imposed on early-weaned calves within each age group for period 1. For earlyweaned calves, period 1 consisted of 12 days on pen-fed diet plus 15 days on pasture with supplemental feed. Differences in
ADG were not expected because diets were the same for all early-weaned calves during the pen feeding period and the first 15 days on pasture. After day 15 on pasture, early-weaned calves of the 15-day supplementation treatment received no supplemental feed. During the following period, (period 2) all age groups of this treatment (S15 calves) showed lower $(\mathrm{P}<0.05)$ ADG compared with period 1. Group AGE3 3 S15 reached the lowest rate of gain of this trial in this period. The switch of diet to $100 \%$ forage may explain this effect. During the same period, 45-day supplemented early-weaned calves (S45) maintained similar ( $\mathrm{P}>0.25$ ) ADG to period 1. This response would be expected because diet did not change in this treatment. Consequently, ADG of 15-day supplemented early-weaned calves were lower $(\mathrm{P}<0.05)$ than gains of 45 -day supplemented early-weaned calves. Body weight differences, however, between supplementation treatments were not detected yet $(\mathrm{P}>0.34)$ for the oldest calves. Forty five-day supplemented early-weaned calves were 5 and $8 \mathrm{~kg}$ heavier $(\mathrm{P}<0.05)$ than 15-day supplemented early-weaned calves in the intermediate and youngest groups, respectively (Table 7).

After 30 days on forage diet (period 3), the oldest and intermediate age groups of 15-day supplemented early-weaned calves maintained $(\mathrm{P}>0.24)$ ADG compared with period 2. The youngest group (AGE3) increased $(\mathrm{P}<0.05)$ ADG during this period. In the same period, supplemental feeding of calves in the 45-day supplementation treatment (S45) was stopped, and ADG of this treatment decreased $(\mathrm{P}<0.05)$ compared with period 2. The switch of diets may have been the main factor responsible for this ADG depression. During this period, ADG of 15-day supplemented early-weaned calves from the oldest and intermediate age groups were greater $(\mathrm{P}<0.05)$ than ADG of 45-day supplemented calves (Table 8). On day 87 , body weights for calves from the 15 and 45-day supplementation treatments within the oldest and the intermediate age groups, did not differ $(\mathrm{P}>0.17)$, but weights between supplementation treatments were different $(\mathrm{P}<0.05)$ for the youngest group.

In period 4, ADG of 45-day supplemented early-weaned calves of all age groups and 15-day supplemented earlyweaned calves from the intermediate and the youngest groups increased $(\mathrm{P}<0.05)$, compared to gains achieved in period 3 . Both supplementation treatments (S15 and $\mathrm{S} 45)$ had similar $(\mathrm{P}>0.15)$ ADG within age groups during this period. Similarly, a month later (period 5) no differences were detected $(P>0.43)$ between supplementation treatments of early-weaned calves within age group. Over the 148-day period, no differences in $\mathrm{BW}$ were detected ( $\mathrm{P}$ $>0.22$ ) between supplementation treatments for the oldest and the intermediate age groups (Table 7). Differences, however, were evident in the youngest group ( $P$ $<0.01)$.

Overall ADG increased $(\mathrm{P}<0.05)$ with weaning age within the 15-day supplementation treatment for early-weaned calves. A similar trend was noted for the 45-day supplementation treatment, although no differences in overall ADG were detected $(\mathrm{P}=0.16)$ between the oldest and the intermediate (111 and 91 days of age at weaning) groups in this treatment. Gain increased $(\mathrm{P}<0.05)$ also with length of supplementation period within 
Table 8. Average daily gain (ADG, $g$ animal ${ }^{-1}$ ) of Angus calves early weaned (EW) at 3 different ages and supplemented on pasture for 15 (S15) or 45 (S45) days, compared with ADG of calves normally weaned $(\mathrm{NW})^{1,2}$.

\begin{tabular}{|c|c|c|c|c|}
\hline \multirow{2}{*}{$\begin{array}{l}\text { Age at } \\
\text { early weaning }\end{array}$} & \multicolumn{2}{|c|}{ EW calves } & \multicolumn{2}{|c|}{ NW calves } \\
\hline & $\mathrm{S} 15$ & $\mathrm{~S} 45$ & & $\mathrm{SE}^{4}$ \\
\hline & \multirow{2}{*}{\multicolumn{4}{|c|}{$\left(\mathrm{g}\right.$ animal $\left.^{-1}\right)$}} \\
\hline & & & & $\cdots$ \\
\hline AGE1 & $647^{\mathrm{aA} \psi}$ & $641^{\mathrm{aA} \psi}$ & $643^{\mathrm{aA} \psi}$ & 9.7 \\
\hline AGE2 & $590^{\mathrm{aB} \psi}$ & $597^{\mathrm{aB} \psi}$ & $626^{\mathrm{bAB} \psi}$ & 7.7 \\
\hline AGE3 & $552^{\mathrm{aC} \psi}$ & $550^{\mathrm{aC} \psi}$ & $609^{\mathrm{bB} \psi}$ & 11.1 \\
\hline $\mathrm{SE}^{5}$ & 10.3 & 9.9 & 8.5 & 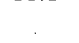 \\
\hline AGEl & $485^{\mathrm{aA \theta}}$ & $638^{\mathrm{bA} \psi}$ & $681^{\mathrm{cA \theta \gamma}}$ & 11.1 \\
\hline AGE2 & $449^{\mathrm{aB} \theta}$ & $594^{\mathrm{bB} \psi}$ & $678^{\mathrm{cA \theta} \gamma}$ & 8.3 \\
\hline AGE3 & $352^{\mathrm{aC} \theta}$ & $552^{\mathrm{bC} \psi}$ & $697^{\mathrm{cAq}}$ & 11.1 \\
\hline SE & 6.9 & 8.1 & 14.5 & \\
\hline AGEl & $526^{\mathrm{a} A \theta \lambda}$ & $458^{\mathrm{bA \theta}}$ & $661^{\mathrm{cA} \psi \theta}$ & 11.5 \\
\hline AGE2 & $463^{\mathrm{aB} \theta}$ & $441^{\mathrm{bA \theta}}$ & $659^{\mathrm{cA \theta} \theta}$ & 7.1 \\
\hline AGE3 & $398^{\mathrm{aC \lambda}}$ & $404^{\mathrm{aB} \theta}$ & $653^{\mathrm{bA \theta}}$ & 9.3 \\
\hline SE & 11.2 & 6.6 & 10.1 & \\
\hline AGE1 & $520^{\mathrm{aA} \lambda}$ & $517^{\mathrm{aA} \lambda}$ & $516^{\mathrm{aA} \lambda}$ & 10.1 \\
\hline AGE2 & $524^{\mathrm{aA} \lambda}$ & $517^{\mathrm{aA} \lambda}$ & $510^{\mathrm{aA} \lambda}$ & 8.1 \\
\hline AGE3 & $431^{\mathrm{aB} \gamma}$ & $453^{\mathrm{aB} \lambda}$ & $448^{\mathrm{aB} \lambda}$ & 20.7 \\
\hline SE & 10.5 & 11.6 & 18.9 & \\
\hline AGE1 & $532^{\mathrm{aA} \lambda}$ & $541 \mathrm{aA} \lambda$ & $693^{\mathrm{bA \gamma}}$ & 10.0 \\
\hline AGE2 & $535^{\mathrm{aA} \lambda}$ & 529 aA $\lambda$ & $699^{\mathrm{bA} \gamma}$ & 13.2 \\
\hline AGE3 & $440^{\mathrm{aB} \gamma}$ & $444 \mathrm{aB} \lambda \theta$ & $777^{\mathrm{bB} \gamma}$ & 18.6 \\
\hline SE & 13.1 & 19.9 & 7.5 & \\
\hline AGE1 & $540^{\mathrm{aA}}$ & $557^{\mathrm{bA}}$ & $639^{\mathrm{cA}}$ & 5.1 \\
\hline AGE2 & $511^{\mathrm{aB}}$ & $534^{\mathrm{bA}}$ & $635^{\mathrm{cA}}$ & 5.6 \\
\hline AGE3 & $432^{\mathrm{aC}}$ & $479^{\mathrm{bB}}$ & $638^{\mathrm{cA}}$ & 9.5 \\
\hline \multirow[t]{2}{*}{$\mathrm{SE}$} & 6.7 & 8.7 & 6.5 & \\
\hline & $\ldots$ & SE for perio & isons $^{7}-$ & $\cdots$ \\
\hline AGE1 & 12.5 & 14.0 & 17.7 & \\
\hline AGE2 & 6.8 & 11.9 & 8.0 & \\
\hline AGE3 & 11.6 & 10.3 & 9.8 & \\
\hline
\end{tabular}

Calves of the NW treatment were kept with the dams until day 87 of trial. Normally weaned calves were 196,178 , and 162 days of age for groups AGE1, AGE2 and AGE3, respectively, at weaning.

${ }_{3}^{2} \mathrm{~A}$ weaning treatment $\mathrm{x}$ age group $\mathrm{x}$ period interaction was detected $(\mathrm{P}<0.001)$; therefore, interactive means are reported.

${ }^{3}$ Age groups at early-weaning date (day 0 of trial): AGE1 $=111 \pm 2.2$ days of age; AGE2 $=91 \pm 1.6$ days of age, and $\mathrm{AGE} 3=75 \pm 3.8$ days of age.

${ }_{5}^{4} \mathrm{SE}=$ Standard error for diet effect.

${ }^{5} \mathrm{SE}=$ Standard error for age group effect.

${ }^{6}$ Period $1=$ ADG between day 0 and 27 of trial, Period $2=$ between day 27 and 57; Period $3=$ between day 57 and 87 ; Period $4=$ between day 87 and 117 ; Period $5=$ between day 117 and 148 .

${ }^{7} \mathrm{SE}=$ Standard error for period effect within age group and diet.

${ }^{a b c}$ Row means with different lowercase superscripts differ $(\mathrm{P}<0.05)$.

${ }^{A B C}$ Column means within period with different uppercase superscripts differ $(\mathrm{P}<0.05)$.

${ }^{\text {yqlg }}$ Column means within age group across periods with different superscripts differ $(\mathrm{P}<0.05)$.

and across weaning ages. Within early weaning treatments, calves weaned at the youngest age ( 75 days of age) were the group most affected by the diets imposed, and those in this age group receiving supplement for only 15 days experienced the lowest overall rate of growth.

Reports on compared performance of early-weaned calves exposed to limited supplementation programs are scarce. Early weaning on a $100 \%$ forage diet compared to a $1.1 \mathrm{~kg} \mathrm{day}^{-1}$ animal $^{-1}$ of supplemental feed was reported by Simeone et al. (1997). Supplemented early-weaned calves gained $310 \mathrm{~g} \mathrm{day}^{-1}$ more than nonsupplemented ones. most affected under feeding programs that use a supplementation period on pasture shorter than 45 days.

Shortening of supplementation period on pasture to 15 days after weaning can have negative effects on performance. The effect, however, would be less dramatic if calves are 90-day old or older at weaning time. If calves are younger, supplementation during at least 45 days may be necessary to achieve an acceptable rate of growth. More research is needed to develop improved options that combine adequate calf growth and reduced costs without compromising future calf performance. Questions such as calf age and weight, forage quality, and supplement level interactions remain to be addressed in future research on early weaning.

\section{Literature Cited}

AOAC. 1990. Official methods of Analysis (15 $5^{\text {th }}$ Ed.). Assoc. of Official Analytical Chem., Washington, DC.

Fernández, G.D. and A.E. Zúcari. 1996. Efecto del destete precoz sobre la performance reproductiva en vaquillonas de primera parición. Rev. Arg. Prod. Anim. 16(1):49.

Fernández, G.D., A.E. Zúcari, and E.L. Antón. 1997. Efecto de la edad del destete sobre la performance de vacas de refugo y ternero. Rev. Arg. Prod. Anim. 17(1):279.

Fluharty, F.L., S.C. Loerch, T.B. Turner, S.J. Moeller, and G.D. Lowe. 2000. Effects of weaning age and diet on growth and carcass characteristics in steers. J. Anim. Sci. 78:1759-1767.

Gill, D.R., F. N. Owens, M.C. King, and H.G. Dolezal. 1993. Body composition of grazing or feedlot steers differing in age and background. Okla. Agr. Exp. Sta. Res. Rep. pp. 993:185-190.

Goering, H.K. and P.J. Van Soest. 1970. Forage fiber analyses (apparatus, reagents, procedures, and some applications). Agr. Handb. 379. ARS, USDA, Washington, D.C.

Hidalgo, L.G., S. Callejas, M.A. Cauhepé, and M.J. Otero. 1996. Efecto del destete precoz sobre la condición corporal y la preñez en vacas multíparas. Rev. Arg. Prod. Anim. 16(1):36.

Our study provides evidence that early weaning at 2 to 3 months of age, with proper feeding, is a feasible technique to reduce herd requirements without affecting calf performance. Moreover, in cases of feed restrictions for the cows and calves, it could favor not only the cow, but also the calf.

Low-cost feeding programs can successfully be implemented, however, calf requirements should not be underestimated. Results from this study indicate that 70 to 80 day-old weaned calves would be the
Hofer, C.C., J.J. Bruno, and A.R. Monje. 1984. Comportamiento de terneros destetados a los 60 días de edad. Manejo del destete y método de crianza. EEA INTA C. Del Uruguay. Prod. Anim. Inf. Téc. 1:126-132.

Holechek, J.L. and B.D. Gross. 1982. Evaluation of diet selection in ruminants. Functional Ecol. 2:15-22.

Holechek, J.L., M. Vavra, and R. D. Pieper. 1982. Botanical determination of range herbivore diets: a review. J. Range Manage. 35:309-315. 
Kugler, N.M., H. Giorgetti, G. Cecchi, G. Rodriguez, y O. Montenegro. 1997a. Módulos de cría: Destete precoz vs convencional. Jornadas de cría en campos de monte. EEA Valle Inferior de Río Negro, IDEVIINTA p. 52-53.

Kugler, N.M., H. Giorgetti, G. Cecchi, G. Rodriguez, y O. Montenegro. 1997b. Destete precoz e incremento en la carga animal. 1. Efecto sobre los vientres. Rev. Arg. Prod. Anim. 17(1):269.

Laster, D.B., H.A. Climp, and K.E. Gregory. 1973. Effects of early weaning on paspartum reproduction of cows. J. Anim. Sci. 36:734-740.

Lusby, K.S. and A.A. Parra. 1981. Effects of early weaning on calf performance and on reproduction in mature cows. Okla. Agr. Exp. Sta. Rep. MP 108:64-68.

Lusby, K.S. and R.P. Wettemann. 1980. Effects of early weaning calves from first calf heifers on calf and heifer performance. Okla. Agr. Exp. Sta. Res. Rep. MP 107:55-58.

Lusby, K.S., R.P. Wettemann, and E.J. Turman. 1981. Effects of early weaning calves from first-calf heifers on calf and heifer performance. J. Anim. Sci. 53:11931197.

Lusby, K.S., D.R. Gill, D.M. Anderson, T.L Gardner, and H.G. Dolezal. 1990. Limit feeding vs full feeding high concentrate diets to early-weaned calves- effects on performance to slaughter. Okla. Agr. Exp. Sta. Res. Rep. MP 129:128-134.
Monje, A.R., C.C. Hofer, and I.O. Galli. 1978. Destete precoz y creep-feeding. Efecto sobre la receptividad. AAPA Prod. Anim. 6:391-396.

Monje, A.R., C.C. Hofer, and I.O. Galli. 1993. Destete precoz: Efecto sobre los vientres, manejo de los terneros e impacto de la técnica sobre los sistemas de producción. Memorias. Jornada de difusión técnica: Destete precoz en cría vacuna. EEA INTA C. Del Uruguay. pp.13-38.

Myers, S.E., D.B. Faulkner, F.A. Ireland, and, D.F. Parrett. 1999a. Comparison of three weaning ages on cow-calf performance and steer carcass traits. J. Anim. Sci. 77:323-329.

Myers, S.E., D.B. Faulkner, F.A. Ireland, L.L. Berger, and D.F. Parrett. 1999b. Production systems comparing early weaning to normal weaning with or without creep feeding for beef steers. J. Anim. Sci. 77:300-310.

National Research Council. 1996. Nutrient requirements of beef cattle. Seventh Revised Ed. Washington D.C.: National Academy Press.

Peterson, O.W., T.B. Turner, K.M. Irvin, M. E. Davis, H. W. Newland, and W. R. Harvey. 1987. Cow and calf performance and economic considerations of early weaning of fall-born beef calves. J. Anim. Sci. 64:15-22.
Roberto, Z.E., G. Casagrande, and E.F Viglizzo, 1996. Lluvias en la pampa central. Tendencias y variaciones del siglo. Cambio climático y agricultura sustentable en la región pampeana. Ed. INTA PEI 2:3-25.

Robertson, J.B. and P.J. Van Soest. 1981. The detergent system analysis and its applications to human foods: $I n$ : W.P.T. James and O. Theander (Ed.) The Analysis of Dietary Fiber. pp 123-158. Marcell Dekker, New York.

SAS. 1991. Statistics Analysis System User's Guide. SAS Institute Inc. Cary. N.C.

Sciotti, A.E., J. Carrillo, L.M. Melucci and A. Cano. 1996. Efecto del destete precoz en vacas primíparas y de última parición sobre los pesos y ganancias de peso de los terneros y sus madres. Rev. Arg. Prod. Anim. 16(1):30.

Simeone, A., A.I. Trujillo, G. Córdoba, J. Gil, M. Rodríguez, A. Bejerez, R. Zanoniani, F. Baccino, and M. Umpierrez. 1997. Efecto del destete precoz y de dos sistemas de alimentación post-destete sobre la ganancia de peso de terneros Hereford hasta los 15 meses de edad. Rev. Arg. Prod. Anim. 17(1):58.

Sparks, D.R. And J.C. Malechek. 1968. Estimating percentage dry weight in diets using a microscopic technique. J. Range Manage. 21:264-265.

Tilley, J.M.A. and R.A. Terry. 1963. A twostage technique for in vitro digestion of forage crops. J. Brit. Grassl. Soc. 18:104. 